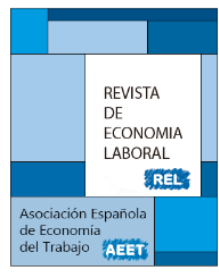

\title{
KNOWLEDGE CAPITAL AND PRODUCTIVITY IN SPANISH INDUSTRY ${ }^{1}$
}

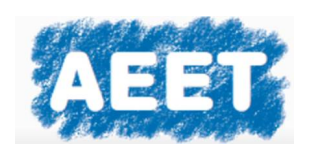

\author{
César Rodríguez-Gutiérrez ${ }^{2}$ and Juan Francisco Canal-Domínguez \\ Universidad de Oviedo
}

Recibido Octubre 2020; Aceptado Diciembre 2020

\begin{abstract}
This research is aimed at measuring the effects of firms' knowledge capital stock changes in production, using the information provided by a panel of Spanish industrial firms. In order to assess the size of these effects depending upon the type of industry, we split the sample into two broad branches of business activity: Low and Medium-low (LML), and High and Medium-high (HMH) technological firms. Estimate outcomes show that the elasticity of output with respect to knowledge capital is always positive and significant. Moreover, the highest productivity gains derived from innovation are observed in High and Medium-high technological firms.
\end{abstract}

Key words: $R \& D$ expenditures, knowledge capital, innovation, productivity.

JEL Classification: D24, J23, O33

\section{Resumen}

Esta investigación trata de medir los efectos de los cambios en el stock de capital tecnológico de las empresas sobre la producción, utilizando la información proporcionada por un panel de empresas industriales españolas. Para calcular el tamaño de esos efectos dependiendo del tipo de industria, la muestra de empresas se divide en dos amplias ramas de actividad: empresas de tecnología baja y media-baja y empresas de tecnología alta y media-alta. Las estimaciones muestran que la elasticidad del producto con respecto al capital tecnológico es siempre positiva y significativa. Además, las mayores ganancias de productividad derivadas de la innovación se observan en las empresas de alta y mediaalta tecnología.

Palabras clave: gasto en $I+D$, capital tecnológico, innovación, productividad. Clasificación JEL: D24, J23, O33

1 This article was supported by the Spanish Ministry of Economy, Industry and Competitiveness [Project ECO2017-86402-C2-1-R] and the University of Oviedo [Project PAPI-19-GR-2014-0076].

2 Emails: crodri@uniovi.es and jfcanal@uniovi.es

(C) Revista de Economía Laboral 


\section{Introducción}

The total research and development (R\&D) expenditure closely reflects firm's innovation level, either measured as an annual flow or as an accumulated expenditure (computed as knowledge capital stock). The central idea is that $\mathrm{R} \& \mathrm{D}$ expenditure allows companies to generate innovation that, in turn, increases productivity. The most widespread measurement of this productivity gain is the elasticity of output with respect to innovation. To compute this elasticity, we need to estimate a production function, which since Griliches (1973), incorporates a measurement of firms' knowledge capital stock built by aggregating prior R\&D expenditures.

In that sense, the main goal of this paper is estimating output elasticity with respect to knowledge capital for Spanish industrial firms. Moreover, following Goya et al. (2016), we will try to see how this elasticity varies between two broad industrial branches (Low and Medium-low technological firms and High and Medium-high technological ones). To measure the impact of innovation on output we use a database offering information at the firm level about innovation expenditure for the period 2008-2016. It also provides information on investment expenditure (that allows calculating the stock of physical capital), sales and firms' employment. This database is the Panel de Innovación Tecnológica-PITEC (Technological Innovation Panel), carried out by the Instituto Nacional de Estadistica-INE (Spanish Statistical Office). This period includes a first stage of deep crisis, between 2008 and 2013, during which both production and employment plunged; and a last stage of growth, from 2014 to 2016, during which the economy began a slow recovery. The collapse of the Spanish economy from 2008 to 2013 is displayed in Figure 1. This collapse is mainly pictured by one figure: Spanish unemployment rate was 8.23 per cent in 2007, at the peak of the previous boom period, and increased to 17.88 per cent in 2009 . That is, in just two years (2008 and 2009) the unemployment rate multiplied by a little more than two, and even reach 26.09 per cent in 2013. Moreover, and spite of what it could be inferred from the existence of GDP growth rates higher than 3 per cent from 2015 onwards, job destruction during 2008 and 2009 was so intense that Spanish unemployment rate remained higher than 19 per cent in 2016.

The extremely high levels of unemployment suffered by the Spanish labour market during economic slumps, and the great difference in the unemployment rate in relation to the European average that is 
observed even in periods of strong economic growth (for example, in 2007), reflect an obvious problem of competitiveness in the Spanish economy, maybe because of poor innovation level at companies. Data from the Estadistica de Actividades de $I+D$ (Statistics on R\&D Activities) for 2018 show that Spain is well below the European average in terms of the intensity of $R \& D$ spending. Thus, while the percentage of total internal expenditure on R\&D in relation to GDP for the EU-28 is 2.03, the corresponding value for Spain is 1.24 and, for example, that corresponding to Germany is 3.13. If, as it will be seen below, spending on innovation is a key factor to increase firms' productivity, it is clear that research and development and innovation promotion should be a fundamental goal in the employment policy.

The research is structured as follows. First of all, a summary of the previous literature on this topic is presented. Second, the methodology that allows identifying the effect of innovation on output is described. Third, such effect is estimated from the Spanish panel data used. Finally, the main conclusions of the research are summarised.

Figure 1. Interannual variation rates of employment and GDP at market prices in Spain (Chain-linked volume index), 2007-2016. Source: Annual Spanish National Accounts (Spanish Statistical Office-INE).

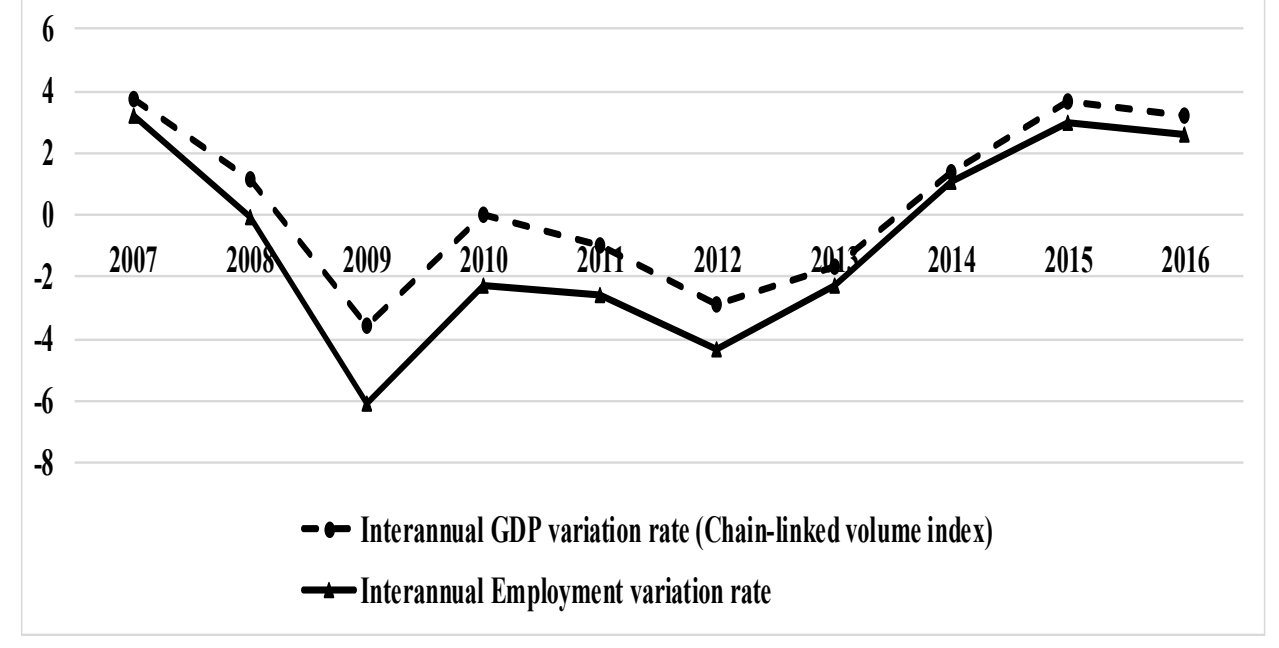




\section{Previous research}

Many authors have found evidence of a positive relationship between R\&D expenditure and productivity. In this sense, Griliches (1998a) and Mairesse and Mohnen (1990) quote several articles from the 1980s and 1990s that confirm the existence of this positive relationship. Besides, one may cite, for example, Cuneo and Mairesse (1984) and Crépon et al. (1998) for the French case; Kafouros (2005) for the British case; and Janz et al. (2004) for the German and Swedish cases. On the other hand, Griffith et al. (2006) carried out a study for four countries (France, Germany, Spain, and the UK) finding, as a differential fact, that this positive relationship is very weak in Germany.

Referring specifically to the Spanish case, several papers have addressed this issue using primarily two databases: the Panel de Innovación Tecnológica-PITEC and the Encuesta Sobre Estrategias Empresariales-ESEE (Business Strategy Survey), provided by the Spanish Ministry of Industry. Goya et al. (2016) and Barge-Gil et al. (2019) used the first database, while a higher number of researchers were inclined to use the second one. Among others, one may quote, for example, the papers by Beneito (2001), García et al. (2002), Huergo and Jaumandreu (2004), Maté and Rodríguez (2008), Huergo and Moreno (2011), Doraszelsky and Jaumandreu (2013, 2018), and Añón-Higón et al. (2018).

As far as the papers using PITEC data are concerned, Goya et al. (2016) analysed the influence on firms' performance of innovation applied by other firms belonging to the same sector (intra-industry spillovers) and to other sectors (inter-industry spillovers). Using data for the period 2004-2009, they concluded that R\&D stock did not have a direct impact on firms' performance, while spillovers do. In a similar vein, Barge-Gil et al. (2019) used data for the period 2005-2013 to focus on the existence of technological spillovers from multinational firms. They stated that horizontal spillovers (intra-industry linkages) were the larger ones, followed by backward (vertical) spillovers.

As for the articles using ESEE data for the 90s, Beneito (2001) also analysed the spillover effects of innovation. She concluded that these spillover effects were only relevant for those firms that use advanced technologies. On the other hand, the positive effects of innovation on productivity were estimated by Huergo and Jaumandreu (2004) in the case of process innovation; by García et al. (2002), who proxied innovation by the knowledge capital of firms; by Maté and Rodríguez (2008), who 
used the R\&D intensity ( $R \& D$ expenditure divided by the real value added) as an index of technological effort; and, finally, by Doraszelsky and Jaumandreu (2013). Extending the sample of ESEE to more recent years, Huergo and Moreno (2011) and Doraszelsky and Jaumandreu (2018) continued to find evidence of this positive relationship. Finally, Añón-Higón et al. (2018), using data from period 1991-2014, analysed two R\&D strategies: intramural $R \& D$ and external $R \& D$, observing that R\&D strategies only offered a total factor productivity (TFP) premium to exporters.

In spite of the great empirical evidence found on this issue, there are still some relevant questions that we can try to answer using recent databases from different countries. For instance: Does the effect of knowledge capital on productivity vary with the activity sector? In the case of U.S. manufacturing firms, Hall (2005) calculates R\&D productivity in six broad technology-based sectors using data for the period 1974-2003. She concludes that productivity is highly variable among sectors. In the next sections, we will try to answer this question for the Spanish case.

\section{How to measure the effect of innovation on output}

Going back to the way innovation is measured, some research uses firms' annual R\&D expenditure. However, to use this data directly does not seem to be very appropriate. Innovation is a process involving continuous and cumulative learning and testing, whose outcomes are sometimes only obtained after years of researching in a given direction. For this reason, most authors have been using indicators related to the knowledge capital acquired by firms during the years they were spending on R\&D. ${ }^{3}$

Following Hall (2005), we assume a Cobb-Douglas production function augmented with a knowledge capital term. Taking logarithms and using $i$ to represent firms and $t$ to denote time, the production function could be expressed as follows:

$$
\log Y_{i t}=\varphi_{i}+\gamma_{t}+\alpha \log L_{i t}+\beta \log C_{i t}+\varepsilon \log K_{i t}+\mu_{i t}
$$

\footnotetext{
${ }^{3}$ Although this methodology is widely accepted, the use of knowledge capital as a way of measuring a firm's innovation capacity presents some weaknesses, which were pointed out by Griliches (1998b).
} 
where $Y_{i t}$ is the output; $\varphi_{i}$ represents a specific firm effect that does not change over time; $y_{t}$ is a time effect that remains the same at all firms; $L_{i t}$ is the labour input; $C_{i t}$ denotes the physical capital stock; $K_{i t}$ is the knowledge capital stock accumulated by the firm during its existence; and $\mu_{i t}$ is the error term. Parameter $\varepsilon$ is the elasticity of output with respect to knowledge capital, and it measures the effect of innovation on production.

As far as equation [1] is concerned, Hall (2005) makes a caveat that should be taken into account. If the researcher holds information on firm sales (as it is our case) instead of an output measurement, then what it is being estimated is a "revenue production function" rather than a production function. That is, if the variable to be explained is defined as the product of the amount sold by the price set by firms, except if we can use an internal deflator to eliminate the own-price effect, the impact of knowledge capital captured by parameter $\varepsilon$ includes both innovation contribution to productivity and to prices (innovation could lead to cost savings, and therefore, to lower prices). This way, $\varepsilon$ will not be exactly measuring the direct effect of innovation on productivity (which requires constant prices), but rather it could be partially stating an indirect effect via lower prices. Since we selected a PITEC subsample corresponding to industrial firms, we may avoid this problem. The INE (Spanish Statistical Office) provides industrial price indexes (IPRI) taking 2015 as base year for 29 branches of activity. Therefore, we can deflate firms' sales by the appropriate price index in order to express values in real terms. ${ }^{4}$ On the other hand, we should point out that PITEC does not provide information about intermediate inputs.

\footnotetext{
4 The classification into 29 branches of activity (divisions) of the IPRI does not exactly coincide with the one used by the PITEC. Therefore, adaptations have been required. For example, the index assigned to the PITEC division "Food, beverages \& tobacco" for the period 2008-2016 is the average of divisions 10 ("Food"), 11 ("Beverages") and 12 ("Tobacco") price indices from IPRI. On the other hand, the PITEC "Ship building" and "Aircraft \& spacecraft" sections are assigned the IPRI corresponding to "Other transport equipment". Regarding the period 2004-2007, the PITEC "Games \& toys" division is assigned the "Other manufactures" IPRI, and in the case of "Radio, TV \& communication equipment" division, the index assigned is that of "Electrical machinery \& apparatus".
} 


\section{Estimates of the innovation effect on output}

\subsection{Data}

The database used in this research is the Panel de Innovación Tecnológica-PITEC. To estimate the model, we will use the sample corresponding to period 2008-2016. Complementarily, the model will be estimated for a larger sample (for period 2004-2016). These estimates are not strictly comparable with the first ones, since the changes made in the survey questionnaire over time allow computing a new variable that is included in the model for period 2008-2016 but is not available for period 2004-2016.

This dataset, which has been widely used in research papers, is based on the Community Innovation Survey (CIS) carried out by Eurostat and covers all activity sectors. In addition to the aforementioned papers by Goya et al. (2016) and Barge-Gil et al. (2019), it may be quoted, for example, the papers by Rojas-Pizarro (2013) and Ciriaci et al. (2016), who studied the effect of innovation on employment for the Spanish economy. The total sample includes almost all the firms that carry out R\&D expenditures (they are easy to be surveyed, because they are included in a special directory of firms by INE) and also those firms with 200 or more employees. As for the rest of cases, sampling is at random. ${ }^{5}$

The quantitative variables used in this research to estimate the production function, expressed in logarithms, are the following: firm sales $\left(\log Y_{i t}\right)$; gross investment, out of which physical capital stock $\left(\log C_{i t}\right)$ is computed; number of workers $\left(\log L_{i t}\right)$; and total expenditure on innovation, that allows estimating knowledge capital stock $\left(\log K_{i t}\right) .{ }^{6}$

Following Griliches (1973, 1979) and García et al. (2002), knowledge capital of each firm is built as the weighted sum of previous innovation expenditures, using the perpetual inventory method. ${ }^{7}$ So, the

\footnotetext{
${ }^{5}$ Survey methodology is available at: https://www.ine.es/daco/daco43/metoite2018.pdf.

6 As PITEC methodology explains, all variables have undergone a statistical anonymization process, being replaced by simulated figures obtained as the average values of 3 or 5 similar firms (criteria used were activity branch and firm size) (See: https://www.ine.es/prodyser/microdatos/metodologia_pitec.pdf). On the other hand, the values of all monetary variables (sales, gross investment and total innovation expenditure) have been deflated to 2015 euro-value.

7 Innovation expenditures include internal and external R\&D expenditures plus other minor expenditures, such as external knowledge acquisition and formation. This variable is named 'total innovation expenditures' (GTINN) in PITEC.
} 
knowledge capital of a given year is supposed to be the one of the previous year less its depreciation plus the innovation expenditure of the previous year. This way, it is assumed that innovation expenditure takes one year to show benefits. In order to compute this variable, a 15 per cent knowledge capital depreciation rate has been used. ${ }^{8}$ Regarding the calculation of the physical capital stock, the procedure is the same except for the fact that capital depreciation rate is supposed to be 5 per cent. ${ }^{9}$

Since our analysis focuses on industry, we have only used the PITEC subsample of industrial firms. Moreover, we split this subsample into two broad branches of business activity: Low and Medium-low (LML), and High and Medium-high (HMH) technological firms. We use the criteria proposed by Goya et al. (2016) to consider a specific branch of industry as HMH or LML Tech. Table A1 of Appendix lists the industrial branches included in each group of firms, that are slightly different before and after 2008, since the Economic Activity Classification used by PITEC changes in that year. ${ }^{10}$ Descriptive statistics for the variables used in the estimates are displayed in Table 1. It is observed that all the variables (real sales, knowledge capital, employment) have higher values for the subsample of HMH Tech firms than for the subsample of LML Tech companies, except in the case of capital stock for period 2004-2016.

\footnotetext{
8 As Hall (2005) points out, this depreciation rate is the one used in most researches estimating knowledge capital stock, maybe being influenced by Griliches' first papers. This is also the rate used by Hall and Mairesse (1995) and by García et al. (2002) for the Spanish case.

9 This rate was used to compute the physical capital stock by Nadiri and Prucha (1996). In turn, they used a 12 per cent depreciation rate for the knowledge capital. On the other hand, Levy (1995) estimated an approximate 5 per cent depreciation rate for 'Nonresidential Business Structures' for the 1948-1991 period in the U.S. This rate is slightly lower than the statistic depreciation rate estimated for the Spanish economy by EscribáPérez et al. (2017), which ranged between 5.8 and 7.5 per cent for the period 1965-2011. Finally, Bond et al. (2003) assume an 8 per cent depreciation rate for the case of a sample of German, British, Belgian and French manufacturing firms.

10 PITEC uses CNAE1993 before 2008 and CNAE2009 after this year.
} 
Table 1. Variable descriptive statistics. Source: PITEC.

a) Period 2008-2016

\begin{tabular}{|c|c|c|c|c|c|c|}
\hline \multirow[b]{2}{*}{ Variable } & \multicolumn{2}{|c|}{$\begin{array}{l}\text { All industrial } \\
\text { firms }\end{array}$} & \multicolumn{2}{|c|}{$\begin{array}{l}\text { HMH Tech } \\
\text { firms }\end{array}$} & \multicolumn{2}{|c|}{$\begin{array}{l}\text { LML Tech } \\
\text { firms }\end{array}$} \\
\hline & Mean & SD & Mean & SD & Mean & SD \\
\hline Log of real sales & 16.094 & 1.893 & 16.148 & 1.951 & 16.057 & 1.852 \\
\hline Log of number of workers & 4.051 & 1.439 & 4.102 & 1.468 & 4.014 & 1.417 \\
\hline Log of capital stock & 15.310 & 2.269 & 15.344 & 2.306 & 15.286 & 2.241 \\
\hline Log of knowledge capital & 13.257 & 3.319 & 13.769 & 3.091 & 12.895 & 3.426 \\
\hline $\begin{array}{l}\text { Percentage of employees with } \\
\text { university degree }\end{array}$ & 19.529 & 19.727 & 23.637 & 21.552 & 16.620 & 17.761 \\
\hline Process or product innovation & 0.689 & 0.463 & 0.731 & 0.443 & 0.660 & 0.474 \\
\hline 2008 & 0.132 & 0.338 & 0.130 & 0.337 & 0.133 & 0.339 \\
\hline 2009 & 0.132 & 0.338 & 0.130 & 0.336 & 0.133 & 0.339 \\
\hline 2010 & 0.126 & 0.331 & 0.124 & 0.330 & 0.127 & 0.333 \\
\hline 2011 & 0.121 & 0.326 & 0.119 & 0.324 & 0.125 & 0.327 \\
\hline 2012 & 0.115 & 0.320 & 0.113 & 0.317 & 0.116 & 0.321 \\
\hline 2013 & 0.110 & 0.313 & 0.109 & 0.312 & 0.111 & 0.314 \\
\hline 2014 & 0.087 & 0.282 & 0.090 & 0.287 & 0.085 & 0.278 \\
\hline 2015 & 0.085 & 0.278 & 0.088 & 0.284 & 0.082 & 0.274 \\
\hline 2016 & 0.094 & 0.292 & 0.096 & 0.294 & 0.092 & 0.290 \\
\hline Total number of observations & \multicolumn{2}{|c|}{42,137} & \multicolumn{2}{|c|}{17,465} & \multicolumn{2}{|c|}{24,672} \\
\hline \multicolumn{7}{|l|}{ b) Period 2004-2016 } \\
\hline & \multicolumn{2}{|c|}{$\begin{array}{l}\text { All industrial } \\
\text { firms }\end{array}$} & \multicolumn{2}{|c|}{$\begin{array}{l}\text { HMH Tech } \\
\text { firms }\end{array}$} & \multicolumn{2}{|c|}{$\begin{array}{l}\text { LML Tech } \\
\text { firms }\end{array}$} \\
\hline Variable & Mean & SD & Mean & SD & Mean & SD \\
\hline Log of real sales & 16.138 & 1.873 & 16.153 & 1.942 & 16.127 & 1.821 \\
\hline Log of number of workers & 4.076 & 1.418 & 4.092 & 1.454 & 4.066 & 1.391 \\
\hline Log of capital stock & 15.225 & 2.298 & 15.192 & 2.355 & 15.249 & 2.255 \\
\hline Log of knowledge capital & 13.211 & 3.374 & 13.792 & 3.014 & 12.783 & 3.556 \\
\hline Process or product innovation & 0.723 & 0.447 & 0.769 & 0.422 & 0.690 & 0.462 \\
\hline 2004 & 0.071 & 0.257 & 0.076 & 0.265 & 0.068 & 0.251 \\
\hline 2005 & 0.087 & 0.282 & 0.091 & 0.288 & 0.085 & 0.279 \\
\hline 2006 & 0.089 & 0.285 & 0.092 & 0.289 & 0.087 & 0.281 \\
\hline 2007 & 0.088 & 0.284 & 0.091 & 0.288 & 0.086 & 0.281 \\
\hline 2008 & 0.087 & 0.282 & 0.085 & 0.278 & 0.089 & 0.285 \\
\hline 2009 & 0.087 & 0.282 & 0.085 & 0.278 & 0.090 & 0.286 \\
\hline 2010 & 0.083 & 0.277 & 0.081 & 0.272 & 0.086 & 0.280 \\
\hline 2011 & 0.080 & 0.272 & 0.077 & 0.267 & 0.082 & 0.275 \\
\hline 2012 & 0.076 & 0.266 & 0.074 & 0.261 & 0.079 & 0.269 \\
\hline 2013 & 0.073 & 0.260 & 0.071 & 0.257 & 0.075 & 0.263 \\
\hline 2014 & 0.058 & 0.233 & 0.059 & 0.235 & 0.057 & 0.232 \\
\hline 2015 & 0.056 & 0.230 & 0.057 & 0.233 & 0.055 & 0.228 \\
\hline 2016 & 0.062 & 0.242 & 0.062 & 0.241 & 0.062 & 0.242 \\
\hline Total number of observations & \multicolumn{2}{|c|}{63,444} & \multicolumn{2}{|c|}{26,890} & \multicolumn{2}{|c|}{36,554} \\
\hline
\end{tabular}




\subsection{Estimates}

The fact of having a data panel available allows controlling unobserved heterogeneity and eliminating fixed effects by taking first differences. It also allows controlling endogeneity problems arising from some model variables. Particularly, in a production function such as equation [1], employment $\left(\log L_{i t}\right)$ and knowledge capital $\left(\log K_{i t}\right)$ may be considered endogenous variables, as they are determined jointly with production $\left(\log Y_{i t}\right) .{ }^{11}$ For such reason, when estimating equation [1], employment and knowledge capital must be instrumented in order to correct this bias. Table 2 shows the outcomes of estimating a fixed effect model for panel data using xtivreg 2 STATA command for period 20082016 and for three different subsamples: all industrial firms, HMH Tech firms and LML Tech firms. This option estimates a Two-Stage Least Squares-2SLS model, being standard errors robust to heteroskedasticity. In order to instrument $\log L_{i t}$ and $\log K_{i t}$ we use the values of employment lagged two and three periods, and also the percentage of employees with university degree and a dummy variable that takes the value one when the firm reports the introduction of a process or product innovation in the last three years. The set of instruments also includes all exogenous variables. An endogeneity test has been carried out for both variables. This test is distributed as a $\chi^{2}$ with two degrees of freedom. The null hypothesis is that knowledge capital and employment are exogenous. The values of these tests are $28.645(\mathrm{p}=0.000), 15.346(\mathrm{p}=0.0005)$ and $13.348(\mathrm{p}=0.001)$ depending on the sample used. Therefore, it may be stated that both variables are endogenous, given that the null hypothesis is rejected. ${ }^{12}$

\footnotetext{
11 See, for example, García et al. (2002).

12 As far as the quality of estimates is concerned, Table 2 shows the Hansen J statistics. This is an overidentification test of all instruments. The null hypothesis is the validity of overidentifying restrictions. In this case, given its values $(1.428 / \mathrm{p}=0.490,0.943 / \mathrm{p}=0.624$ and $0.663 / \mathrm{p}=0.718$ ), we should not reject such null hypothesis. On the other hand, the Kleinbergen-Paap rk LM statistics is a test to know whether the model is underidentified. Since the null hypothesis is that the excluded instruments are not correlated with the endogenous regressor, then we should have to reject the null hypothesis for instruments to be valid. Given that test values are $179.196 / \mathrm{p}=0.000,135.378 / \mathrm{p}=0.000$ and $80.815 / \mathrm{p}=0.000$, the null hypothesis is rejected.
} 
Table 2. Firm's production function estimates (IV/Two-Stages Least Squares estimation). Period: 2008-2016

\begin{tabular}{|c|c|c|c|c|c|c|}
\hline \multirow[b]{3}{*}{ Independent variables: } & \multicolumn{6}{|c|}{ Dependent variable: Log of real sales } \\
\hline & \multicolumn{2}{|c|}{ All industrial firms } & \multicolumn{2}{|c|}{$\begin{array}{l}\text { High and Medium-High } \\
\text { Technological firms }\end{array}$} & \multicolumn{2}{|c|}{$\begin{array}{l}\text { Low and Medium-Low } \\
\text { Technological firms }\end{array}$} \\
\hline & Coefficient & $\mathbf{z}$ & Coefficient & $\mathbf{z}$ & Coefficient & $\mathbf{z}$ \\
\hline Log of number of workers I & 0.554 & $8.42^{* *}$ & 0.541 & $8.02^{* *}$ & 0.562 & $5.36^{* *}$ \\
\hline Log of capital stock & 0.189 & $8.11 * *$ & 0.135 & $4.25^{* *}$ & 0.225 & $6.68^{* *}$ \\
\hline Log of knowledge capital I & 0.189 & $6.40^{* *}$ & 0.233 & $4.92^{* *}$ & 0.158 & $4.30^{* *}$ \\
\hline 2009 & -0.178 & $-18.37 * *$ & -0.178 & $-13.64 * *$ & -0.176 & $-12.54 * *$ \\
\hline 2010 & -0.163 & $-14.23^{* *}$ & -0.155 & $-11.19 * *$ & -0.166 & $-9.39 * *$ \\
\hline 2011 & -0.168 & $-14.24^{* *}$ & -0.175 & $-12.13^{* *}$ & -0.163 & $-8.82^{* *}$ \\
\hline 2012 & -0.215 & $-16.00 * *$ & -0.216 & $-13.66^{* *}$ & -0.214 & $-9.97 * *$ \\
\hline 2013 & -0.218 & $-14.56^{* *}$ & -0.195 & $-11.70^{* *}$ & -0.232 & $-9.41^{* *}$ \\
\hline 2014 & -0.172 & $-12.80 * *$ & -0.146 & $-9.54 * *$ & -0.186 & $-8.52^{* *}$ \\
\hline 2015 & -0.124 & $-10.20 * *$ & -0.095 & $-6.39 * *$ & -0.145 & $-7.45^{* *}$ \\
\hline 2016 & -0.118 & $-9.48 * *$ & -0.085 & $-5.00 * *$ & -0.144 & $-7.89 * *$ \\
\hline $\mathrm{F}(11 ; 34,225)$ & & 389.58 & & - & & - \\
\hline $\mathrm{F}(11 ; 14,148)$ & & - & & 155.61 & & - \\
\hline $\mathrm{F}(11 ; 19,891)$ & & - & & - & & 241.84 \\
\hline Hansen J statistic $\chi^{2}(2)$ (overidentification test) & & 1.428 & & 0.943 & & 0.663 \\
\hline Kleinbergen-Paap rk LM $\chi^{2}(3)$ (underidentification test) & & 179.196 & & 135.378 & & 80.815 \\
\hline Kleinbergen-Paap rk Wald F (weak identification test) & & 42.188 & & 39.374 & & 18.705 \\
\hline Endogeneity test for $\chi^{2}(2)$ & & 28.645 & & 15.346 & & 13.348 \\
\hline
\end{tabular}

Notes: (I) Instrumented variable. Excluded instruments: Percentage of employees with university degree; Dummy variable that takes the value one when the firm reports the introduction of a process or product innovation in the last three years; Number of workers ( $t$-2); Number of workers (t-3). Corrected standard errors are consistent with panel-specific autocorrelation and heteroskedasticity in one-step estimation.

** and * represent significance at the 5 per cent and 10 per cent level, respectively. 
In relation to the values of the relevant elasticities of the model, we observe that all coefficients are significant and have the expected sign. Output elasticities with respect to employment are 0.554 for all industrial firms, 0.541 for $\mathrm{HMH}$ firms and 0.562 for LML; and with respect to physical capital are $0.189,0.135$ and 0.225 , respectively. Finally, $\varepsilon$ estimated values are 0.189 for all firms, 0.233 for HMH firms and 0.158 for LML firms. Therefore, the effect of innovation on output is always significant and it seems to be greater the higher the technological level of firms. This result is as expected, since those companies with the widest technological base are the ones that can generate the highest productivity increases due to $R \& D$ investments. ${ }^{13}$ In that case, an increase of 1 per cent in knowledge capital leads to a 0.233 per cent increase in firms' output. The value of this elasticity is within the variation range estimated in some prior studies conducted for other countries when samples of High-Tech firms are used. ${ }^{14}$

On the other hand, the negative effect of the economic slump starting in 2008 is clearly observed in the negative sign of the coefficients of year dummies (the reference category is year 2008). The values of the coefficients of year dummies also show that the drop in production with respect to 2008 decreases from 2014, especially in the case of $\mathrm{HMH}$ firms. Once again, we see that high-tech companies are better able to translate economic recovery into production gains than low-tech ones.

In order to test the stability of these outcomes, we proceed to enlarge the used sample by estimating the model for period 2004-2016. As we pointed out above, during the first years of this period the survey did not report information about a central variable that was used to instrument knowledge capital in the estimates for period 2008-2016. This variable is the percentage of employees with university degree. Therefore, estimates are not strictly comparable in both cases. Results corresponding to period 2004-2016 are displayed in Table 3.

\footnotetext{
13 Goya et al. (2016), using "innovation output" (not R\&D expenditures) as a measure of innovation also conclude that the impact of innovation is greater for those firms belonging to high-tech sector. Similar differences among sectors are obtained by Segarra-Blasco (2020) for the case of Catalonia.

${ }^{14}$ In order to know some of these estimates see, for example, Mairesse and Mohnen (1990, p. 102). These types of companies are called "scientific firms" by Mairesse and Mohnen.
} 
Table 3. Firm's production function estimates (IV/Two-Stages Least Squares estimation). Period: 2004-2016 Dependent variable: Log of real sales

\begin{tabular}{|c|c|c|c|c|c|c|}
\hline \multirow[b]{2}{*}{ Independent variables: } & \multicolumn{2}{|c|}{ All industrial firms } & \multicolumn{2}{|c|}{$\begin{array}{l}\text { High and Medium-High } \\
\text { Technological firms }\end{array}$} & \multicolumn{2}{|c|}{$\begin{array}{l}\text { Low and Medium-Low } \\
\text { Technological firms }\end{array}$} \\
\hline & Coefficient & $\mathbf{z}$ & Coefficient & $\mathbf{z}$ & Coefficient & $\mathbf{z}$ \\
\hline Log of number of workers I & 0.639 & $9.11^{* * *}$ & 0.617 & $8.00^{* * *}$ & 0.652 & $5.15^{* *}$ \\
\hline Log of capital stock & 0.166 & $7.35^{* *}$ & 0.122 & $4.09^{* *}$ & 0.198 & $5.24^{* *}$ \\
\hline Log of knowledge capital I & 0.183 & $6.61^{* *}$ & 0.213 & $4.55^{* *}$ & 0.156 & $4.07 * *$ \\
\hline 2007 & 0.036 & $3.90^{* *}$ & 0.037 & $2.96^{* *}$ & 0.033 & $2.58^{* *}$ \\
\hline 2008 & -0.020 & $-2.20^{* *}$ & -0.004 & -0.27 & -0.016 & -1.10 \\
\hline 2009 & -0.189 & $-14.87^{* *}$ & -0.174 & $-11.16^{* *}$ & -0.183 & $-7.80^{* *}$ \\
\hline 2010 & -0.168 & $-11.34^{* *}$ & -0.145 & $-8.85^{* *}$ & -0.168 & $-5.86^{* *}$ \\
\hline 2011 & -0.169 & $-11.14^{* *}$ & -0.163 & $-9.67^{* *}$ & -0.159 & $-5.41^{* *}$ \\
\hline 2012 & -0.211 & $-12.51^{* *}$ & -0.201 & $-11.04^{* *}$ & -0.205 & $-6.19^{* *}$ \\
\hline 2013 & -0.210 & $-11.60^{* *}$ & -0.178 & $-9.46^{* *}$ & -0.218 & $-6.03^{* *}$ \\
\hline 2014 & -0.162 & $-9.97^{* *}$ & -0.130 & $-7.51^{* *}$ & -0.170 & $-5.27^{* *}$ \\
\hline 2015 & -0.116 & $-7.91 * *$ & -0.080 & $-4.85^{* *}$ & -0.132 & $-4.52^{* *}$ \\
\hline 2016 & -0.111 & $-7.62^{* *}$ & -0.072 & $-4.04^{* *}$ & -0.131 & $-4.84^{* *}$ \\
\hline $\mathrm{F}(13 ; 41,513)$ & & 592.08 & & & & \\
\hline $\mathrm{F}(13 ; 17,024)$ & & - & & 192.31 & & - \\
\hline $\mathrm{F}(13 ; 23,359)$ & & - & & & & 321.92 \\
\hline Hansen J statistic $\chi^{2}(1)$ (overidentification test) & & 0.013 & & 0.323 & & 0.018 \\
\hline Kleinbergen-Paap rk LM $\chi^{2}(2)$ (underidentification test) & & 99.587 & & 48.423 & & 46.329 \\
\hline Kleinbergen-Paap rk Wald F (weak identification test) & & 17.390 & & 15.142 & & 6.568 \\
\hline Endogeneity test for $\chi^{2}(2)$ & & 26.663 & & 9.257 & & 15.792 \\
\hline
\end{tabular}

Notes: (I) Instrumented variable. Excluded instruments: Dummy variable that takes the value one when the firm reports the introduction of a process or product innovation in the last three years; Number of workers (t-2); Number of workers (t-3). Corrected standard errors are consistent with panelspecific autocorrelation and heteroskedasticity in one-step estimation.

** and * represent significance at the 5 per cent and 10 per cent level, respectively. 
There are some differences between these outcomes and previous results (for example, the values of the output elasticity with respect to employment are higher in all the cases), but the effect of knowledge capital remains stable. ${ }^{15}$

\section{Conclusions}

The total effect of innovation on output may be computed by estimating a traditional production function augmented with a knowledge capital term. It is better to use this variable instead of the annual expenditure on $R \& D$, as innovation is a cumulative process that may take years to produce benefits. The database used is a panel of Spanish industrial firms, which were followed up over a long period. Since employment and knowledge capital are endogenous variables in the estimation of a production function, we use a method of estimation that allow correcting both endogeneity bias as the unobserved heterogeneity: IV/Two-Stage Least Squares. Moreover, we built two subsamples depending on the type of industry: Low and Medium-low (LML), and High and Medium-high (HMH) technological companies.

The main outcomes of the estimates are as follows. First, the elasticity of output with respect to knowledge capital is always significant and positive. Second, this effect is higher in the HMH Tech sector than in the LML one. This result is as expected, since companies with the widest technological base are those that can generate the greatest productivity increases due to R\&D investments. Finally, this significant and positive effect of innovation on firms' productivity and, therefore, on the competitiveness of our economy, is an argument in favour of the implementation of economic policies that aim to encourage research, development and innovation if we want to pursue the goal of full employment.

\footnotetext{
15 In any case, we must point out that the positive effect of innovation on productivity could be slightly overestimated due to firms' death and attrition problems if it were the case that less productive companies, especially in slump periods, disappear from the sample (due to cessation of activity) in much greater proportion than the most productive ones.
} 


\section{References}

Añón-Higón, D., Máñez, J. A. and Sanchis-Llopis, J. A. (2018), "Intramural and external R\&D: Evidence for complementarity or substitutability", Economía Política, 35(2), 555-577.

Barge-Gil, A., López, A. and Núñez-Sánchez, R. (2019), "Technological spillovers from multinational firms", MPRA Paper No. 96662, University Library of Munich, Munich. Available at https://mpra.ub.unimuenchen.de/96662/.

Beneito, P. (2001), "R\&D productivity and spillovers at the firm level: evidence from Spanish panel data”, Investigaciones Económicas, 25(2), 289-313.

Bond, S., Elston, J., Mairesse, J. and Mulkay, B. (2003), "Financial factors and investment in Belgium, France, Germany and the United Kingdom. A comparison using company panel data", Review of Economics and Statistics, 85(1), 153-165.

Ciriaci, D., Moncada, P. and Voigt, P. (2016), "Innovation and job creation: A sustainable relation?", Eurasian Business Review, 6(2), 189213.

Crépon, B., Duguet, E. and Mairesse, J. (1998), "Research, innovation, and productivity: An econometric analysis at the firm level", Economics of Innovation and New Technology, 7(3), 115-158.

Cuneo, P. and Mairesse, J. (1984), "Productivity and R\&D at the firm level in French manufacturing", in Griliches, Z. (Ed.), R\&D, patents and productivity, NBER Books, Cambridge MA, 375-392.

Doraszelsky, U. and Jaumandreu, J. (2013), "R\&D and productivity: Estimating endogenous productivity", Review of Economic Studies, 80(4), 1338-1383.

Doraszelsky, U. and Jaumandreu, J. (2018), "Measuring the bias of technological change", Journal of Political Economy, 126(3), 1027-1084. 
Escribá -Pérez, F. J., Murgui-García, M. J. and Ruiz-Tamarit, J. R. (2017), "Economic and statistical measurement of physical capital with an application to the Spanish economy", Discussion Paper No. 2017-20, Institut de Recherches Économiques et Sociales de l'Université Catholique de Louvain-IRES, Louvain.

García, A., Rodríguez, C. and Jaumandreu, J. (2002), "Innovación y empleo: Evidencia a escala de empresa", Economía Industrial, 348, 111118.

Goya, E., Vayá, E. and Suriñach, J. (2016), "Innovation spillovers and firm performance: micro evidence from Spain (2004-2009)", Journal of Productivity Analysis, 45(1), 1-22.

Griffith, R., Huergo, E., Mairesse, J. and Peters, B. (2006), "Innovation and productivity across four European countries", Oxford Review of Economic Policy, 22(4), 483-498.

Griliches, Z. (1973), "Research expenditures and growth accounting", in Williams, B. R. (Ed.), Science and Technology in Economic Growth, MacMillan, London, 59-95.

Griliches, Z. (1979), "Issues in assessing the contribution of research and development to productivity growth", Bell Journal of Economics, 10(1), 92-116.

Griliches, Z. (1998a), R\&D and productivity: The econometric evidence ( $1^{\text {st }}$ ed.), NBER Monograph, University of Chicago Press, Chicago.

Griliches, Z. (1998b), "R\&D and productivity: The unfinished business", Estudios de Economía, 25(2), 145-160.

Hall, B. H. (2005), "Measuring the returns to R\&D: the depreciation problem”, Annales d'Economie et de Statistique, 79-80, 341-381.

Hall, B. H. and Mairesse, J. (1995), "Exploring the relationship between R\&D and productivity in French manufacturing firms", Journal of Econometrics, 65(1), 263-293. 
Huergo, E. and Jaumandreu, J. (2004), "Firms' age, process innovation and productivity growth", International Journal of Industrial Organization, 22(4), 541-559.

Huergo, E. and Moreno, L. (2011), "Does history matter for the relationship between R\&D, Innovation and Productivity?", Industrial and Corporate Change, 20(5), 1335-1368.

Janz, N., Lööf, H. and Peters, B. (2004), "Innovation and productivity in German and Swedish manufacturing firms: Is there a common story?", Problems and Perspectives in Management, 2, 184-204.

Kafouros, M. I. (2005), "R\&D and productivity growth: Evidence from the UK", Economics of Innovation and New Technology, 14(6), 479-97.

Levy, D. (1995), "Capital stock depreciation, tax rules, and composition of aggregate investment", Journal of Economic and Social Measurement, 21(1), 45-65.

Mairesse, J. and Mohnen, P. (1990), "Recherche-Développement et productivité: un survol de la littérature économétrique”, Economie et Statistique, 237-238, 99-108.

Maté-García J. J. and Rodríguez-Fernández, J. M. (2008), "Productivity and R\&D: an econometric evidence from Spanish firm-level data", Applied Economics, 40(14), 1827-1837.

Nadiri, M. I. and Prucha, I. R. (1996), "Estimation of depreciation rate of physical and R\&D capital in the U.S. total manufacturing sector", Economic Inquiry, 34(1), 45-56.

PITEC-Panel de Innovación Tecnológica. (2017), "Metodología”, INE, Madrid. Available at https://www.ine.es/prodyser/microdatos/metodologia_pitec.pdf.

Rojas-Pizarro, F. (2013), "Innovación y empleo en las empresas manufactureras españolas", Working Papers/Documentos de Trabajo DT CCEE-1307, Facultad de Ciencias Económicas y Empresariales, Universidad Complutense de Madrid, Madrid. Available at http://eprints.ucm.es/21841. 
Segarra-Blasco, A. (2010), "Innovation and productivity in manufacturing and service firms in Catalonia: a regional approach", Economics of Innovation and New Technology, 19(3), 233-258. 


\section{Appendix}

\section{Table A1. Branches of industry (correspondence between PITEC before 2008 and PITEC in 2008 and after)}

\begin{tabular}{|c|c|c|c|}
\hline \multicolumn{2}{|c|}{ High and Medium-High Technological firms } & \multicolumn{2}{|c|}{ Low and Medium-Low Technological firms } \\
\hline PITEC BEFORE 2008 & PITEC 2008 AND AFTER & PITEC BEFORE 2008 & PITEC 2008 AND AFTER \\
\hline Coke ovens \& oil refining & Oil refining & Extractive industries & Extractive industries \\
\hline $\begin{array}{l}\text { Chemical products (except } \\
\text { pharmaceuticals) }\end{array}$ & Chemical products & Food \& beverages & Food, beverages \& tobacco \\
\hline Pharmaceutical products & Pharmaceutical products & Tobacco & \\
\hline Machinery \& equipment & Manufacturing & Textile products & Textile products \\
\hline Office machinery \& computers & & Clothing \& furriers & Clothing \\
\hline Electrical machinery \& apparatus & $\begin{array}{l}\text { Electrical machinery, computers, } \\
\text { electronic \& optical instruments }\end{array}$ & Leather \& footwear & Leather \& footwear \\
\hline Electronic components & & Wood \& cork & Wood \& cork \\
\hline Radio, TV \& communication equipment & & Paper products & Carton \& paper \\
\hline $\begin{array}{l}\text { Medical \& optical instruments, watches, } \\
\text { clocks }\end{array}$ & & Publishing \& printing & Publishing \& printing \\
\hline Motor vehicles & Motor vehicles & Rubber \& plastic products & Rubber \& plastic products \\
\hline Aircraft \& spacecraft & Aircraft \& spacecraft & Tiles \& ceramic tiles & \\
\hline Other transport equipment & Other transport equipment & Non-metallic mineral products & Non-metallic mineral products \\
\hline \multirow[t]{9}{*}{ Production of electricity, gas \& water } & Energy \& water & Ferrous metallurgic products & Metallurgic products \\
\hline & $\begin{array}{l}\text { Repair \& instalation of machinery \& } \\
\text { equipment }\end{array}$ & Non-ferrous metallurgic products & \\
\hline & & $\begin{array}{l}\text { Metal products (except machinery \& } \\
\text { equipment) }\end{array}$ & \\
\hline & & Ship building & Ship building \\
\hline & & Furniture & Furniture \\
\hline & & Games \& toys & \\
\hline & & Other manufactures & Other manufactures \\
\hline & & Recycling & \\
\hline & & & $\begin{array}{l}\text { Other machinery \& equipment } \\
\text { Sanitation, waste management \& } \\
\text { decontamination }\end{array}$ \\
\hline
\end{tabular}

